\title{
Exploring Students' Learning Engagement in EFL Online Classroom
}

\author{
Dwi Sloria Suharti ${ }^{*}$, Didi Suherdi, Sri Setyarini
}

\author{
English Education Program, Universitas Pendidikan Indonesia \\ *Corresponding author. Email: dwisloria@upi.edu
}

\begin{abstract}
Due to the pandemic era, the Indonesian government proposes all schooling through online learning, including learning English. The study of students' engagement in EFL online learning is scarce in Indonesia. The aim of this study investigates students' engagement in EFL online classrooms in a vocational school, Indonesia through a descriptive survey. The obtained data were analysed, drawing upon the Online Student Engagement Scale (OSE) proposed by Dixson (2015). The scale includes four categories: behaviour, emotion, involvement, and cognitive on students' engagement while learning English online. The researchers used a questionnaire and video document observation to gather information. The researchers distributed a questionnaire to 33 respondents via WhatsApp Group (WAG) class, and only twenty-three of them gave it back. Then, the researchers obtained video document observation in EFL online class learning from a voluntary EFL teacher. The results showed that using an online language learning platform in the learning process can give EFL students significant learning involvements. A further implication of this study was revealed teachers should explore effective online EFL learning techniques that include assessments.
\end{abstract}

Keywords: EFL student, online learning, student engagement

\section{INTRODUCTION}

Indonesia has taken a new initiative to fix future and current employment problems (Anis \& Anwar, 2020). Since the early 2000s, the Indonesian national curriculum has been considered competency-based. Outcome-based education allows the student to be a professional. And student engagement plays a critical role in their learning and career achievement, as asserted by Setyarini, Muslim, Rukmini, Yuliasri, and Mujianto (2018). Students are motivated to use their logical thought abilities to overcome their life problems in all learning tasks, they argue. Outcome-based education allows the student to be a professional (Subkhan, 2020).

Furthermore, Student engagement at school plays a critical role in their learning and career achievement. Much progress has been made in recognizing student engagement and its position in fostering many successful outcomes (Bundick, Quaglia, Corso, \& Haywood, 2014). To be a professional suit students' learning needs, student engagement in the learning seems essential and promises to plan how they become professional in the field in their future. Student engagement centred mainly on increasing success, positive attitudes, and a sense of belonging. More recently, student engagement was centred around the hopeful aim of inspiring all students. Student engagement was both a learning process and a transparency result (Parsons \& Taylor, 2011). However, student disengagement is typical. Low levels of engagement have been observed in several countries around the world. Students usually lose interest in learning as the school. This issue may be attributed in part to a lack of a clear understanding of how students are engaged (Bundick et al., 2014).

Fredricks and McColsky (2012) define that "engagement" comprises three closely interrelated yet conceptually separate dimensions: behavioural, emotional, and cognitive. "Behavioural engagement" is relating to different learning and instructional activities in which students are engaged. Behaviours of note include engaging in class events, attending classes, obedience to rules, and performing tasks. Emotional engagement relates to students' thoughts towards the interactions with those at school and a feeling of belonging. Cognitive engagement is characterized as a student's degree of interest in learning. There is a great deal of cognitive engagement with this post, ranging from abstract ideas to active questions to mastering the subject. Students' engagement is behaviours, interests, 
and self-efficacy (Zake et al. in Purnawarman, Susilawati, \& Sundayana 2016).

EFL students discover classroom exercises are discouraging and tedious (Mahboob \& Elyas, 2014). Conventional teaching strategies are often repetitive, which may cause students' diminished performance levels and absence of interest. Knowing elements of students' learning engagement is essential. Zhang and McNamara (2018) assert that student and teacher engagement conceptualizations describe three main fields of interaction: behaviours, motivations, relationships. These interactions trigger a student's learning engagement. 3

For Indonesia to succeed internationally, educators must intensively nurture potential skills. EFL teachers should also strengthen their language curriculum to produce internationally competent students efficiently. Motivation is also an essential driver in language learning. The role of motivation in promoting positive affective factors to facilitate language learning is undeniable (Bley-Vroman in Anis \& Anwar, 2020).

Merdeka Belajar's practices can be useful in English Language Teaching to develop student motivation and engage students in learning English. It is a new approach to English language Teaching through the Self-Organized Teaching-Learning Environment (SOLE) Technique. The developer of this theory, Sugata Mitra, successfully experimented with SOLE's concept within India. This report demonstrates Shihab, and Komunitas Guru Belajar (2017) advocated Merdeka Belajar Concept as an educator's viewpoint to be taken into consideration. Self-Organized Teaching-Learning Environment (SOLE) alternates in tackling Indonesia's education problem. It is a new approach to English Language Teaching through the SOLE Technique. The developer of this theory, Sugata Mitra, successfully experimented with SOLE's concept within India (Anis \& Anwar, 2020).

Students revealing intrinsic and extrinsic motivation displayed sincerity, ritual, retreats, and rebellious engagement. When pedagogical reciprocity occurred, intrinsic motivation supported authentic student learning engagement. Students with both forms of motivation displayed different learning engagement types (Saeed \& Zyngier, 2012). They claim that disengaged students' behavior may do their work, but without interest and commitment.

Teachers should consider using extrinsic motivation to boost their students' intrinsic motivation. Motivated and engaged students learn better (Bundick et al., 2014). Respectful relationships and interaction-both virtual and personal-are illustrated to enhance student engagement. Dunleavy and Milton (2009) examined students, their ideal school looks, and what learning atmosphere enhances interaction. Students identified three requirements that align with the interaction concept: (1) Learn from and with each other and people in their community; (2) Engage with experts and expertise; and (3) provide more opportunities for discussion and conversation. Thus, the advantage of more interactive learning settings is the engagement of students. Teachers may play an active role in encouraging student engagement (Bundick et al., 2014). Teachers should know and be responsible for designing academic activities that create extrinsic motivation. Using appropriate pedagogies, teachers can also make classrooms more engaging places for students to learn (Saeed \& Zyngier, 2012). An alternative system called SMSLEFA for the Research Learning Interaction Framework for Synergistic Multi-layered Students is studied by Suherdi (2018). It disclosed that SMSLEFA successfully explained the SLE in a synergistic multilayering way.

Open, caring, supportive relationships are essential for social and psychological learning engagement. Teachers should know and be responsible for designing academic activities that create extrinsic motivation. To learn, students today need social contact (Willms, Friesen, \& Milton, 2009). Students who identify a favourable disciplinary climate are half times more likely to report high levels of interest, motivation, and learning satisfaction. Moreover, exploration stimulates student learning engagement. Claxton (2007) further indicates that learners must have the following factors to engage: importance, obligation, truth, and reality. Today's learners ask that their learning relate wherever possible to real-life scenarios. Working with authentic issues or group issues includes students and builds meaning. Thus, effective teaching is characterized by carefully designing learning activities with such features. Brown (2000) asserts that digital media reshape language - especially oral language.

Table 1. Students' Demographic

\begin{tabular}{llll}
\hline Characteristics & Notes & Frequency & Percentage \\
\hline Gender & Male & 0 & $0 \%$ \\
& Female & 23 & $100 \%$ \\
Age & $16-17$ & 6 & $26,1 \%$ \\
& $17-18$ & 15 & $65,2 \%$ \\
& 18 Above & 2 & $8,7 \%$ \\
Students' site & Home & 23 & $100 \%$ \\
& Dormitory & 0 & $0 \%$ \\
& Others & 0 & $0 \%$ \\
Internet access & & & \\
& Yes & 22 & $95,7 \%$ \\
& No & 1 & $4,3 \%$
\end{tabular}

Teachers (2010) report that technology strengthens student engagement factors. Cell phones, iPhones, and Blackberries boost class participation by up to $78 \%$. Students are inspired to learn using classroom technology. They learn critical 21 st-century skills, such 
as creativity and problem-solving. Hence, technology offers learners relevant topics and experts and a tool for engaged learning. Multimedia and technologies have helped to engage students. Purnawarman et al. (2016) claim technology is used to develop students' learning practices and learning opportunities. Online learning does not run well because it lacks preparation and organizing. Students with high self-confidence, independence, and learning freedom can easily find English learning. It may also affect our nation and its sustainability aspects (Anis \& Anwar, 2020).

Furthermore, Atmojo and Nugroho (2020) reported in their study that the government encourages a new directive policy towards online learning in curriculum education. Online learning does not run well because it lacks preparation and organizing. Results have been carried out via an online class of exercises that involve testing students' engagement.

Students' engagement in online learning is crucial to online learning. It affects students' levels of interest, motivation, and learning outcome satisfaction. Since students learning engagement may promote the success of learning so that the outcome of learning is achieved. Thus, this study aims to answer the primary research question: how EFL students' engagement in online learning in a vocational school in Karawang, Indonesia, is?

\section{METHOD}

This study investigates how EFL students' engagement in online learning in a vocational school in Karawang, Indonesia, using a qualitative approach. This qualitative study transparent allows it easy to share conclusions (Aspers \& Corte, 2019). Austin and Sutton (2014) assert that qualitative analysis cannot yield conclusive results, but it does provide a more in-depth understanding. The type of qualitative study is a qualitative survey. It is used to discover underlying thinking patterns and motives (Jansen, 2010). He asserts that the aim is to consider an issue, challenge, or subject from an individual viewpoint. Surveys apply to a survey of a group by the observation of its participants. Qualitative surveys help come up with theories, which are then evaluated.

The study participants are EFL students aged between 17-18 years old at a vocational school in
Karawang, Indonesia. The data gathered through online questionnaires distributed to WhatsApp's Group (WAG) of an XII grade EFL class majoring in Accounting and Financial Institutions at a vocational school in Karawang, Indonesia. The researchers recruited as many as 23 students from 33 students to fill in the form and took observation data in video recording four times from an EFL teacher who voluntarily participated in this study. It means that the researchers utilize convenient sampling in targeting the students and the teacher as research participants.

The demographic data shows in table 1 that all respondents are female. Their age most frequently belongs to $17-18$ years old, with $65,2 \%$. All the students' site is at home. Mostly they had internet access with $95,7 \%$ valid. Only one student did not have Internet access.

In this study, multiple sources of data are used as part of triangulation. They are the questionnaires and class observation. The researchers examine both data and the Online Student Engagement Scale (OSE) Dixson's (2015) framework. Then, the researchers get consent from the research participant. She let the researchers' survey and record four Accounting and Financial Institutions classes for the XII grade class. The questionnaires and observation results are applied as the primary data source.

The data collection method is not constrained by the study design or form of data to be obtained. Both surveys and participant observations can collect data through questionnaires, monitoring behaviours, or capturing objects (Jansen, 2010). Then, this study gained data from questionnaires and Zoom recording documents. The questionnaires data obtained from the students' engagement in EFL online classes. The researchers drew upon the OSE Dixson's framework. It is primary data analysis. (Dixson, 2015) particularizes the OSE on behaviours, thoughts, and feelings has three essential dimensions: to help an investigation into online class structures, to give criticism to educators about the degree of engagement of their students, and to give proof of instructing adequacy. The OSE scale offers a simple, substantial, and dependable approach to gauge students' engagement in online classes (see figure 1). 


$\begin{array}{ll}\text { Features } & \text { Investigations } \\ \text { Behavior } & \text { I1: Make sure to study English lessons regularly. } \\ \text { I3: Stay up on the reading English texts } \\ \text { I4: Look over class notes between getting online to } \\ \text { make sure I understand the material } \\ \text { I5: Be organized in online English learning. } \\ \text { I6: Take good English notes over the material } \\ \text { showed in PPT or Zoom meeting class } \\ \text { I7: Listen or read the English material delivered } \\ \text { carefully } \\ \text { I2: Put forth effort in learning English } \\ \text { I8: Find ways to make English lesson relevant to } \\ \text { daily activity } \\ \text { I9: Apply English to daily activity. } \\ \text { I10: Find ways to make the English course } \\ \text { interesting to learn English } \\ \text { I11: Desire to leasher } \\ \text { I12: Have fun in English online class chats, } \\ \text { discussions, or via email with the teacher or other } \\ \text { students } \\ \text { I13: Participate actively in English small-group } \\ \text { discussion forums } \\ \text { I14: Help peers in learning English. } \\ \text { I17: Engage in conversations English online class: } \\ \text { chat, discussions, or email } \\ \text { I18: Post in English language discussion forum } \\ \text { online platforms regularly } \\ \text { I19: Get to know other students in English Zoom } \\ \text { meeting or WAG class } \\ \text { I16: Do well on the English tests/quizzes } \\ \text { I15: Get good scores in English lesson } \\ \text { Involvement }\end{array}$

Figure 1 Students' engagement features and their investigation items.

The researchers performed an electronic survey/ questionnaire to gather data from participants. It utilized a Likert scale composed of 5-point scales to define how well the participant represented their behaviour, emotion, involvement, and cognitive engagement in online EFL language platforms. Researchers utilized Zoom recording document observation as additional data to accomplish the primary data analysis. After 23 respondents submitted their questionnaires and the researchers transcribed the recordings, the researchers analysed the data with a statistical tool, JASP (2020), for descriptive statistics showing each response's frequency and percentage. The researchers organized questionnaires into tables and transcription for spread analysis and fixed the validation by associating the data to answer the research question.

\section{FINDINGS AND DISCUSSION}

The data were first described, categorized, organized, clarified, and systematically classified. The transcript was translated to be evaluated into four types of online students' engagement: behaviour, emotion, involvement, and cognition. And the data findings as follow.

\subsection{The Students' Behavioural Engagement}

Following this, present an analysis of the students' behavioural engagement in English online learning. In this case, table 2 is illuminating data from the questionnaires.
Table 2. The students' behavioral engagement: study English regularly

\begin{tabular}{lcccc}
\hline \multicolumn{5}{l}{ Frequencies for I 1. Make sure to study English regularly } \\
I 1. & Frequency & \multicolumn{3}{c}{$\begin{array}{l}\text { Valid } \\
\text { Cumulative } \\
\text { Make }\end{array}$} \\
$\begin{array}{l}\text { sure to } \\
\text { study }\end{array}$ & & Percent & $\begin{array}{l}\text { Percent } \\
\text { Percent }\end{array}$ \\
$\begin{array}{l}\text { English } \\
\text { regularly }\end{array}$ & & & & \\
\hline $\mathbf{1}$ & 2 & 8.696 & 8.696 & 8.696 \\
$\mathbf{2}$ & 1 & 4.348 & 4.348 & 13.043 \\
$\mathbf{3}$ & 8 & 34.783 & 34.783 & 47.826 \\
$\mathbf{4}$ & 11 & 47.826 & 47.826 & 95.652 \\
$\mathbf{5}$ & 1 & 4.348 & 4.348 & 100.000 \\
Missing & 0 & 0.000 & & \\
Total & 23 & 100.000 & & \\
\hline
\end{tabular}

Table 2 shows the most frequent students' behavioural engagement in "studying English regularly" $47.826 \%$ valid, with 11 frequency in the students' positive characteristics.

Table 3. The students' behavioural engagement: staying up on the reading English texts

\begin{tabular}{|c|c|c|c|c|}
\hline \multicolumn{5}{|c|}{ Frequencies for I 3. Stay up on the reading English texts } \\
\hline $\begin{array}{l}\text { I 3. Stay up on } \\
\text { the reading } \\
\text { English texts }\end{array}$ & Frequency & Percent & $\begin{array}{l}\text { Valid } \\
\text { Percent }\end{array}$ & $\begin{array}{l}\text { Cumulative } \\
\text { Percent }\end{array}$ \\
\hline 1 & 2 & 8.696 & 8.696 & 8.696 \\
\hline 3 & 10 & 43.478 & 43.478 & 52.174 \\
\hline 4 & 10 & 43.478 & 43.478 & 95.652 \\
\hline 5 & 1 & 4.348 & 4.348 & 100.000 \\
\hline Missing & 0 & 0.000 & & \\
\hline
\end{tabular}




$\begin{aligned} & \text { Frequencies for I 3. Stay up on the reading English texts } \\ & \text { I 3. Stay up on } \\ & \text { the reading Frequency Percent } \\ & \text { English texts } \\ & \text { Total } \\ & \begin{array}{l}\text { Valid } \\ \text { Percent }\end{array} \\ & \text { The same most frequent students' behavioural } \\ & \text { Percent }\end{aligned}$
engagement of staying up on the reading English texts
are valid in $43.478 \%$ with each ten frequency in the
students' positive and moderately characteristic.

Table 4. The students' behavioural engagement: class notes between getting online English class

\begin{tabular}{|c|c|c|c|c|}
\hline \multicolumn{5}{|c|}{$\begin{array}{c}\text { Frequencies for I 4. Look over class notes between getting } \\
\text { online English class to make sure I understand the } \\
\text { material }\end{array}$} \\
\hline $\begin{array}{l}\text { I } 4 \text {. Look } \\
\text { over class } \\
\text { notes } \\
\text { between } \\
\text { getting } \\
\text { online } \\
\text { English } \\
\text { class to } \\
\text { make sure I } \\
\text { understand } \\
\text { the material }\end{array}$ & Frequency & Percent & $\begin{array}{l}\text { Valid } \\
\text { Percent }\end{array}$ & $\begin{array}{l}\text { Cumulative } \\
\text { Percent }\end{array}$ \\
\hline 1 & 2 & 8.696 & 8.696 & 8.696 \\
\hline 3 & 8 & 34.783 & 34.783 & 43.478 \\
\hline 4 & 6 & 26.087 & 26.087 & 69.565 \\
\hline 5 & 7 & 30.435 & 30.435 & 100.000 \\
\hline Missing & 0 & 0.000 & & \\
\hline Total & 23 & 100.000 & & \\
\hline
\end{tabular}

$34.783 \%$ of the most frequent students' behavioural engagement with 8 responded positively on the scale of 2. Others are seven students with strong characteristics of the students' behaviour.

Table 5. The students' behavioural engagement: being organized in online English learning

\begin{tabular}{lllll}
\hline \multicolumn{1}{c}{ Frequencies for I 5. Be organized in the online English } \\
learning & & & \\
$\begin{array}{l}\text { I 5. Be organized } \\
\text { in the online } \\
\text { English learning }\end{array}$ & Frequency Percent & $\begin{array}{c}\text { Valid } \\
\text { Percent }\end{array}$ & $\begin{array}{l}\text { Cumulative } \\
\text { Percent }\end{array}$ \\
\hline $\mathbf{1}$ & 2 & 8.696 & 8.696 & 8.696 \\
$\mathbf{2}$ & 2 & 8.696 & 8.696 & 17.391 \\
$\mathbf{3}$ & 8 & 34.783 & 34.783 & 52.174 \\
$\mathbf{4}$ & 8 & 34.783 & 34.783 & 86.957 \\
$\mathbf{5}$ & 3 & 13.043 & 13.043 & 100.000 \\
Missing & 0 & 0.000 & & \\
Total & 23 & 100.000 & & \\
\hline
\end{tabular}

As table 5 shows, 8 out of 23 participants in students' behavioral engagement for being organized in the online English learning responded positively on scale 4 to Investigation 5 (I5) with $34.783 \%$ valid.
Table 6. The students' behavioral engagement: taking notes over English readings, PowerPoints, or Zoom meeting class

\begin{tabular}{lllll}
\hline \multicolumn{4}{c}{$\begin{array}{c}\text { Frequencies for I 6. Take good notes over English } \\
\text { readings, PowerPoints, or Zoom meeting class }\end{array}$} \\
$\begin{array}{l}\text { I 6. Take good } \\
\text { notes over }\end{array}$ \\
$\begin{array}{l}\text { English readings, } \\
\text { PowerPoints, or }\end{array}$ \\
$\begin{array}{l}\text { Zoom meeting } \\
\text { class }\end{array}$ & & & & \\
\hline $\mathbf{1}$ & & & & \\
Valid & Cumulative & \\
P & 2 & 8.696 & 8.696 & 8.696 \\
$\mathbf{4}$ & 6 & 26.087 & 26.087 & 34.783 \\
$\mathbf{5}$ & 9 & 39.130 & 39.130 & 73.913 \\
Missing & 6 & 26.087 & 26.087 & 100.000 \\
Total & 0 & 0.000 & & \\
\hline
\end{tabular}

The most significant frequency of the students' behavioural engagement in "taking notes over English readings, PowerPoints, or Zoom meeting class" is 9 participants on the scale of 5.6 participants replied with strong positive and moderate characteristics of this investigation.

Table 7. The students' behavioural engagement: listening/reading the English material

\begin{tabular}{lllll}
\hline \multicolumn{4}{c}{ Frequencies for I 7. Listen/read the English material } \\
carefully \\
$\begin{array}{l}\text { I 7. Listen/read } \\
\text { the English } \\
\text { material } \\
\text { carefully }\end{array}$ & Frequency Percent & $\begin{array}{l}\text { Valid } \\
\text { Percent }\end{array}$ & $\begin{array}{l}\text { Cumulative } \\
\text { Percent }\end{array}$ \\
\hline $\mathbf{1}$ & 2 & 8.696 & 8.696 & 8.696 \\
$\mathbf{3}$ & 5 & 21.739 & 21.739 & 30.435 \\
$\mathbf{4}$ & 11 & 47.826 & 47.826 & 78.261 \\
$\mathbf{5}$ & 5 & 21.739 & 21.739 & 100.000 \\
Missing & 0 & 0.000 & & \\
Total & 23 & 100.000 & & \\
\hline
\end{tabular}

In table 7 , the most frequent students' behavioural engagement in "listening/reading the English material carefully" $47.826 \%$ valid, with 11 frequency with the positive characteristic of the students.

\subsection{The Students' Emotional Engagement}

Table 8. The Students' Emotional Engagement: effort in learning English

\begin{tabular}{|c|c|c|c|c|}
\hline \multicolumn{5}{|c|}{ Frequencies for I 2. Put forth effort in learning English } \\
\hline $\begin{array}{l}\text { I 2. Put } \\
\text { forth } \\
\text { effort }\end{array}$ & $\begin{array}{l}\text { In learning } \\
\text { English } \\
\text { Frequency }\end{array}$ & Percent & $\begin{array}{l}\text { Valid } \\
\text { Percent }\end{array}$ & $\begin{array}{l}\text { Cumulative } \\
\text { Percent }\end{array}$ \\
\hline 1 & 3 & 13.043 & 13.043 & 13.043 \\
\hline 3 & 9 & 39.130 & 39.130 & 52.174 \\
\hline 4 & 10 & 43.478 & 43.478 & 95.652 \\
\hline 5 & 1 & 4.348 & 4.348 & 100.000 \\
\hline
\end{tabular}




\begin{tabular}{|c|c|c|c|c|}
\hline \multicolumn{5}{|c|}{ Frequencies for I 2. Put forth effort in learning English } \\
\hline $\begin{array}{l}\text { I 2. Put } \\
\text { forth } \\
\text { effort }\end{array}$ & $\begin{array}{l}\text { In learning } \\
\text { English } \\
\text { Frequency }\end{array}$ & Percent & $\begin{array}{l}\text { Valid } \\
\text { Percent }\end{array}$ & $\begin{array}{l}\text { Cumulative } \\
\text { Percent }\end{array}$ \\
\hline Missing & 0 & 0.000 & & \\
\hline Total & 23 & 100.000 & & \\
\hline
\end{tabular}

Table 8 shows that 10 out of 23 participants in students' behavioural engagement "Putting forth an effort in learning English" responded positively on scale 4 to Investigation 2 (I2), and only 1 participant for the intense favourable investigation.

Table 9. The Students' Emotional Engagement: making the English material relevant to daily activity

Frequencies for I 8. Find ways to make the English material relevant to my daily activity

I 8. Find ways

\begin{tabular}{lllll}
$\begin{array}{l}\text { to make the } \\
\text { English } \\
\text { material } \\
\text { relevant to my } \\
\text { daily activity }\end{array}$ & Frequency Percent & $\begin{array}{l}\text { Valid } \\
\text { Percent }\end{array}$ & $\begin{array}{l}\text { Cumulative } \\
\text { Percent }\end{array}$ \\
\hline $\mathbf{1}$ & 2 & 8.696 & 8.696 & 8.696 \\
$\mathbf{3}$ & 10 & 43.478 & 43.478 & 52.174 \\
$\mathbf{4}$ & 10 & 43.478 & 43.478 & 95.652 \\
$\mathbf{5}$ & 1 & 4.348 & 4.348 & 100.000 \\
Missing & 0 & 0.000 & & \\
Total & 23 & 100.000 & & \\
\hline
\end{tabular}

Table 9 shows the same most frequent students' behavioural engagement. It shows two frequencies with strong negative characteristics of the investigation and one frequency with strong positive results.

Table 10. The Students' Emotional Engagement: applying English to daily activity

\begin{tabular}{lllll}
\hline \multicolumn{5}{c}{ Frequencies for I 9. Apply English to my daily activity } \\
$\begin{array}{l}\text { I 9. Apply } \\
\text { English to my } \\
\text { daily activity }\end{array}$ & Frequency Percent & $\begin{array}{l}\text { Valid } \\
\text { Percent }\end{array}$ & $\begin{array}{l}\text { Cumulative } \\
\text { Percent }\end{array}$ \\
\hline $\mathbf{1}$ & 2 & 8.696 & 8.696 & 8.696 \\
$\mathbf{3}$ & 13 & 56.522 & 56.522 & 65.217 \\
$\mathbf{4}$ & 7 & 30.435 & 30.435 & 95.652 \\
$\mathbf{5}$ & 1 & 4.348 & 4.348 & 100.000 \\
Missing & 0 & 0.000 & & \\
Total & 23 & 100.000 & & \\
\hline
\end{tabular}

In table $10,56.522 \%$ valid of the most frequent students' behavioural engagement is for the "applying English to daily activity" investigation with 13 participants replied to its moderate characteristic.

Table 11. The Students' Emotional Engagement: making the English course interesting

Frequencies for I 10. Find ways to make the English course interesting to me

\begin{tabular}{lllll}
$\begin{array}{l}\text { I 10. Find ways } \\
\text { to make the } \\
\begin{array}{l}\text { English course } \\
\text { interesting to } \\
\text { me }\end{array}\end{array}$ & Frequency Percent & $\begin{array}{l}\text { Valid } \\
\text { Percent }\end{array}$ & $\begin{array}{l}\text { Pumulative } \\
\text { Percent }\end{array}$ \\
\hline $\mathbf{1}$ & 2 & 8.696 & 8.696 & 8.696 \\
$\mathbf{2}$ & 2 & 8.696 & 8.696 & 17.391 \\
$\mathbf{3}$ & 3 & 13.043 & 13.043 & 30.435 \\
$\mathbf{4}$ & 15 & 65.217 & 65.217 & 95.652 \\
$\mathbf{5}$ & 1 & 4.348 & 4.348 & 100.000 \\
Missing & 0 & 0.000 & & \\
Total & 23 & 100.000 & & \\
\hline
\end{tabular}

The most frequent of the students' behavioural engagement "making the English course interesting" is 15 participants on the scale of 4 , positive characteristic of the Investigation no.10 (I10) with $65.217 \%$ valid.

Table 12. The Students' Emotional Engagement: Desire to learn English

\begin{tabular}{lllll}
\hline \multicolumn{4}{c}{ Frequencies for I 11. Desire to learn English } \\
$\begin{array}{l}\text { I 11. Desire } \\
\text { to learn }\end{array}$ & Frequency Percent & $\begin{array}{l}\text { Valid } \\
\text { English }\end{array}$ & $\begin{array}{l}\text { Pumulative } \\
\text { Percent }\end{array}$ & Percent \\
\hline $\mathbf{1}$ & 2 & 8.696 & 8.696 & 8.696 \\
$\mathbf{3}$ & 3 & 13.043 & 13.043 & 21.739 \\
$\mathbf{4}$ & 14 & 60.870 & 60.870 & 82.609 \\
$\mathbf{5}$ & 4 & 17.391 & 17.391 & 100.000 \\
Missing & 0 & 0.000 & & \\
Total & 23 & 100.000 & & \\
\hline
\end{tabular}

Table 12 shows the most frequent students' behavioural engagement "Desire to learn English" $60.870 \%$ valid, with 14 frequency a positive characteristic of this investigation.

\subsection{The Students' Involvement}

Table 13 shows the most frequency is 8 participants on the positive characteristic of students' involvement "having fun in English online class" The same frequency is 3 , each is a negative and strong negative.

Table 13. The Students' Involvement: having fun in English online class

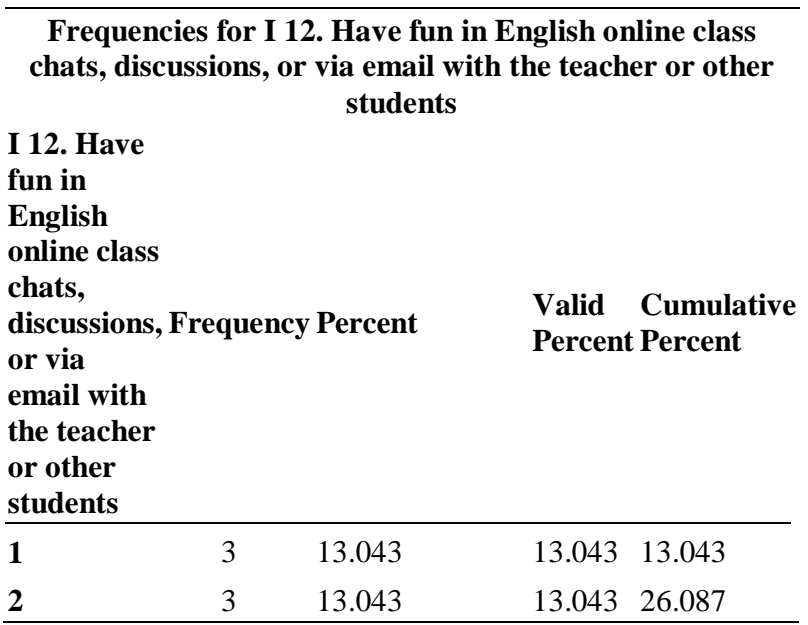




\begin{tabular}{|c|c|c|c|c|}
\hline \multicolumn{5}{|c|}{$\begin{array}{c}\text { Frequencies for I 12. Have fun in English online class } \\
\text { chats, discussions, or via email with the teacher or other } \\
\text { students }\end{array}$} \\
\hline \multicolumn{5}{|c|}{$\begin{array}{l}\text { I } 12 . \text { Have } \\
\text { fun in } \\
\text { English } \\
\text { online class } \\
\text { chats, } \\
\text { discussions, Frequency Percent } \\
\text { or via } \\
\text { email with } \\
\text { the teacher } \\
\text { or other } \\
\text { students }\end{array}$} \\
\hline 3 & 7 & 30.435 & 30.435 & 56.522 \\
\hline 4 & 8 & 34.783 & 34.783 & 91.304 \\
\hline 5 & 2 & 8.696 & 8.696 & 100.000 \\
\hline Missing & 0 & 0.000 & & \\
\hline Total & 23 & 100.000 & & \\
\hline
\end{tabular}

Out of 23 participants in students' involvement "participating actively in an English small-group discussion forum" responded strongly positive to Investigation 13. Others responded only 1 for a negative characteristic of it and 2 participants for the strong positive investigation.

Table 14. The Students' Involvement: participating actively in an English small-group discussion forum

\begin{tabular}{lccll}
\hline \multicolumn{4}{c}{ Frequencies for I 13. Participate actively in an English } \\
small-group discussion forum
\end{tabular}

4 out of 23 participants in students' involvement "participating actively in an English small-group discussion forum" responded strongly positive to Investigation 13. Others responded only 1 for a negative characteristic of it and 2 participants for the strong positive investigation.

Table 15. The Students' Involvement: helping peers in learning English

Frequencies for I 14. Help peers in learning English

\begin{tabular}{lllll}
$\begin{array}{l}\text { I 14. Help } \\
\text { peers in } \\
\text { learning } \\
\text { English }\end{array}$ & Frequency Percent & $\begin{array}{l}\text { Valid } \\
\text { Percent }\end{array}$ & $\begin{array}{l}\text { Cumulative } \\
\text { Percent }\end{array}$ \\
\hline $\mathbf{1}$ & 2 & 8.696 & 8.696 & 8.696 \\
$\mathbf{3}$ & 8 & 34.783 & 34.783 & 43.478 \\
$\mathbf{4}$ & 10 & 43.478 & 43.478 & 86.957 \\
$\mathbf{5}$ & 3 & 13.043 & 13.043 & 100.000 \\
Missing & 0 & 0.000 & & \\
Total & 23 & 100.000 & \\
\hline \multicolumn{4}{c}{$43.478 \%$} & valid of the most frequent students' \\
involvement in the "helping peers in learning English" \\
investigation with 10 participants replied positively.
\end{tabular}

Table 16. The Students' Involvement: engaging in conversations English online class

\begin{tabular}{|c|c|c|c|c|}
\hline \multicolumn{5}{|c|}{$\begin{array}{l}\text { Frequencies for I 17. Engage in conversations English online } \\
\text { class: chat, discussions, or email }\end{array}$} \\
\hline $\begin{array}{l}\text { I 17. Engage in } \\
\text { conversations } \\
\text { English online } \\
\text { class: chat, } \\
\text { discussions, or } \\
\text { email }\end{array}$ & Frequency & Percent & $\begin{array}{l}\text { Valid } \\
\text { Percent }\end{array}$ & $\begin{array}{l}\text { Cumulative } \\
\text { Percent }\end{array}$ \\
\hline 1 & 2 & 8.696 & 8.696 & 8.696 \\
\hline 2 & 1 & 4.348 & 4.348 & 13.043 \\
\hline 3 & 6 & 26.087 & 26.087 & 39.130 \\
\hline 4 & 9 & 39.130 & 39.130 & 78.261 \\
\hline 5 & 5 & 21.739 & 21.739 & 100.000 \\
\hline Missing & 0 & 0.000 & & \\
\hline Total & 23 & 100.000 & & \\
\hline
\end{tabular}

The most frequent of the students' involvement "engaging in conversations English online class" is 9 participants in the scale of 4 , positive characteristic of the Investigation no.17 (I17) with $39.130 \%$ valid.

Table 17. The Students' Involvement: posting in English language discussion forum online

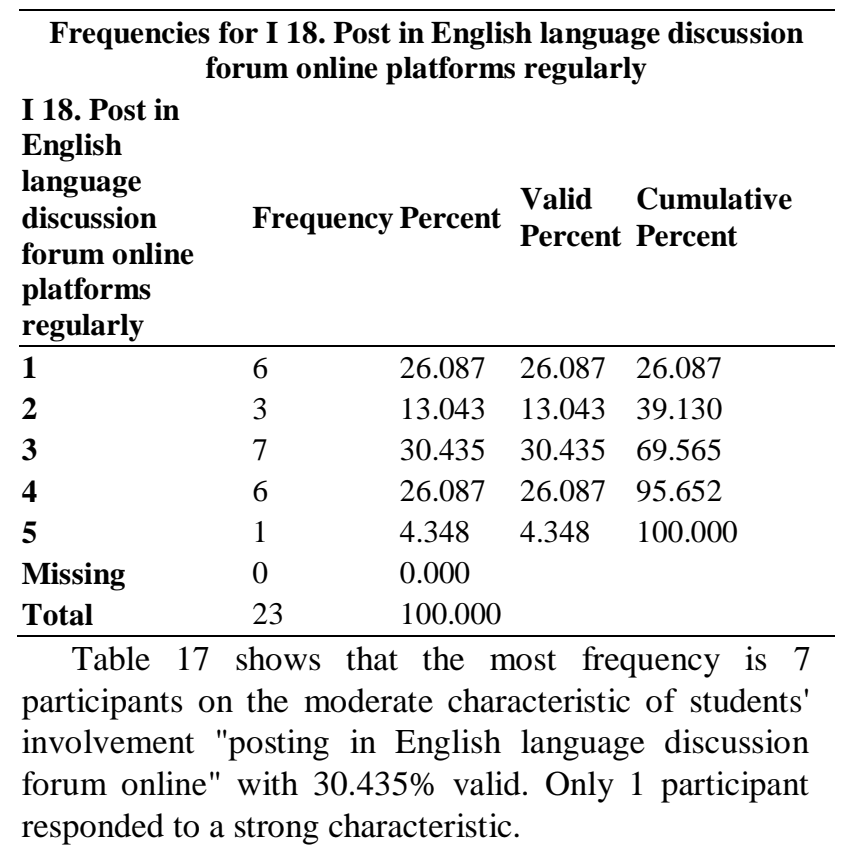


Table 18. The Students' Involvement: getting to know other students in the online class

$\begin{aligned} & \text { Frequencies for I 19. Get to know other students in } \\ & \text { English Zoom meeting or WAG class }\end{aligned}$
$\begin{aligned} & \text { I 19. Get to } \\ & \text { know other } \\ & \text { students in } \\ & \text { English Zoom } \\ & \text { meeting or }\end{aligned}$
WAG class

Table 18 shows six responded moderate and strong characteristics to this investigation with $26.087 \%$ valid. Others responded 5 for negative and 4 for a bit negative characteristic and only 2 for the strong positive investigation.

\subsection{The Students' Cognitive Engagement}

The characteristics of the remaining two types of the students' cognitive engagement are shown in table 19 and 20 .

Table 19. The Students' Cognitive Engagement: getting good scores in English

\begin{tabular}{lllll}
\hline $\begin{array}{l}\text { Frequencies for I 15. Get good scores in English lesson -> } \\
\text { Cognitive }\end{array}$ \\
$\begin{array}{l}\text { I 15. Get } \\
\text { good scores } \\
\text { in English } \\
\text { lesson }\end{array}$ & Frequency Percent & $\begin{array}{l}\text { Valid } \\
\text { Percent }\end{array}$ & $\begin{array}{l}\text { Cumulative } \\
\text { Percent }\end{array}$ \\
\hline $\mathbf{1}$ & 2 & 8.696 & 8.696 & 8.696 \\
$\mathbf{3}$ & 9 & 39.130 & 39.130 & 47.826 \\
$\mathbf{4}$ & 6 & 26.087 & 26.087 & 73.913 \\
$\mathbf{5}$ & 6 & 26.087 & 26.087 & 100.000 \\
Missing & 0 & 0.000 & & \\
Total & 23 & 100.000 & & \\
\hline
\end{tabular}

$39.130 \%$ valid of the most frequent students' cognitive engagement to the "getting good scores in English" investigation with 9 participants responded moderately. 6 participants replied with the strong optimistic

Table 20. The Students' Cognitive Engagement: doing well on the English tests

\begin{tabular}{|c|c|c|c|c|}
\hline \multicolumn{5}{|c|}{ Frequencies for I 16. Do well on the English tests/quizzes } \\
\hline $\begin{array}{l}\text { I 16. Do well } \\
\text { on the English } \\
\text { tests/quizzes }\end{array}$ & Frequency & y Percent & $\begin{array}{l}\text { Valid } \\
\text { Percent }\end{array}$ & $\begin{array}{l}\text { Cumulative } \\
\text { Percent }\end{array}$ \\
\hline 1 & 2 & 8.696 & 8.696 & 8.696 \\
\hline 2 & 1 & 4.348 & 4.348 & 13.043 \\
\hline
\end{tabular}

\begin{tabular}{|c|c|c|c|c|}
\hline Frequencies fo & r I 16. Do w & ell on the & English & tests/quizze \\
\hline $\begin{array}{l}\text { I 16. Do well } \\
\text { on the English } \\
\text { tests/quizzes }\end{array}$ & Frequency & Percent & $\begin{array}{l}\text { Valid } \\
\text { Percent }\end{array}$ & $\begin{array}{l}\text { Cumulative } \\
\text { Percent }\end{array}$ \\
\hline 3 & 10 & 43.478 & 43.478 & 56.522 \\
\hline 4 & 5 & 21.739 & 21.739 & 78.261 \\
\hline 5 & 5 & 21.739 & 21.739 & 100.000 \\
\hline Missing & 0 & 0.000 & & \\
\hline Total & 23 & 100.000 & & \\
\hline
\end{tabular}

The most frequent of the students' cognitive engagement "doing well on the English tests" is 10 participants on the scale of 3 . The same frequency, that is, 5 participants, replied with the strong optimistic and positive characteristic.

From these findings, the researchers revealed that English online classes applied Zoom meetings, Google classroom, and WAG encouraged "Merdeka Belajar" new curriculum/ independent learning. It portrayed students with high self-confidence, independence, and learning freedom. It is in line with Shihab and Komunitas Guru Belajar (2017), Teachers (2010), Atmojo and Nugroho (2020), and Purnawarman et al. (2016) that technology is used to develop students' learning practices and learning opportunities. It is a tool for engaged learning, as Anis and Anwar (2020) argued. They found the students could learn critical 21st-century skills, such as creativity and problem-solving, gathering, translating, and sharing information.

The researchers also found moderate at "stay up on the reading English texts" and "be organized in online English learning" The participants were revealed at eight frequency with the negative characteristic of the "look over class notes over English online class."

The researchers found positive characteristics on students' emotional engagement in English online class learning. It is similar to Willms et al. (2009) asserted that student-teacher-relations are constructive learning environments. Claxton (2007) that learning relates to authentic issues or group issues includes students, and builds meaning. Suherdi (2018) also disclosed that the learning interaction framework is essential for synergistic multi-layered students, and as Brown (2000) believed, digital media reshape language - especially oral language.

The data revealed that students' involvement in English online teaching-learning with almost positive for all. They were moderate at only "post in English language discussion forum online platforms regularly." Those data are similar to Atmojo and Nugroho (2020), and Purnawarman et al. (2016) that technology intensifies students' involvement aspects in English online class platforms.

The researchers revealed all moderate students' cognitive engagement in English online classes for two feature types: "do well on the English tests/quizzes" and 
"get good scores in English lesson" Conversely, they disclosed that students' Cognitive Engagement in English Online Classes.

Researchers obtained four video document observations from the teacher. She was in-depth involved in the students' life experience. She showed simple "cause and effect" writing and helped students identify the sentences' language features. At the end of the class, she gave some topics and asked the students to write a "cause and effect" sentence, the utterances as follows.

\section{Uhm. And I want you to make a sentence based on these uh, based on this. Miss Emma wants you to make a cause and effect sentence based on the words Miss Emi has made like this, yes. There is global warming. There is an earthquake, floods, burning. Just one sentence, you don't need much. You choose two. One student, one student, choose two. Do you want global warming, and where do you choose 2, one sentence? Do you understand? Submit to Google Classroom.}

Figure 2 taken from video document observation's transcription 1 .

The class situation was very interactive. The teacher seemed to try her best to teach the students very favourably. She always praised the students who answered her questions.

At another recording class, the researchers found the teacher was indeed close to the students. She initiated the class by chatting about famous Korean artists such as Dosan and Seo Dami. The example utterances as below.

Teacher: Yes. But the Dosan is really cute, O Allah, he is 187 centimeters tall. [Laughing]

Student: [Laughing] Hmm .. Model.

Teacher: Like mom ..

Student: What's more, if I make a programmer like that, he's really handsome.

Teacher: Ah, especially during that episode when you hacked it, what's his name? Uh, the company. Seo Dami's company was hacked, what time was it about to launch, automatic steering, how handsome it was.

Student: Oh, who just came back from ... America? Oh, yes, America.

Teacher: Oh, those of you who didn't watch it, I'm sorry.

Figure 3 taken from video document observation's transcription 2.

From this observation, the teacher succeeded in making the situation was engaging before teaching. She showed her attention to students' healthy by advising them, "Wash your hands and keep your distance, okay, to stay healthy, okay. Okay, now, um, you are in the third grade because you guys are in third grade, um, okay." After the students were all involved, then she began to elicit the learning topic discussion. The utterances are as following.

Teacher: Okay, now. Those are the Steps in work, then what is the name, the previous step of copying? Graita means you can photocopy now, huh? Nodding Graita [Laughing]

Student: [Laughing]

Teacher: Well, it means that the material that has to do with this is, we are today, we will talk about procedure text. What is the procedure text? What procedure? Step by Step.

Student: Work steps

Teacher: Well, but steps, but now what we are going to learn is um, the manual procedure text, so how do we operate, for example, how do we operate something. Okay, Miss Emi gonna share the screen here.

Figure 4 taken from video document observation's transcription 3.

Then, the teacher gave the example of "procedure text." She made the students practiced after analysing the examples. The practices of procedure texts were all about daily life. It was related to using technology such as sending an email, using the laptop, and steam rice by magic com. She also portrayed to remind the students to do the tasks.

In the third video seemed the teacher has very recognized the students' hobbies, watching Korean drama films. So, she began the conversation in the Korean language. Its story involved them. The situation in the class was very lively. Then, she introduced the topic of learning, writing a simple report of work. The elaboration of the conversation as follows.

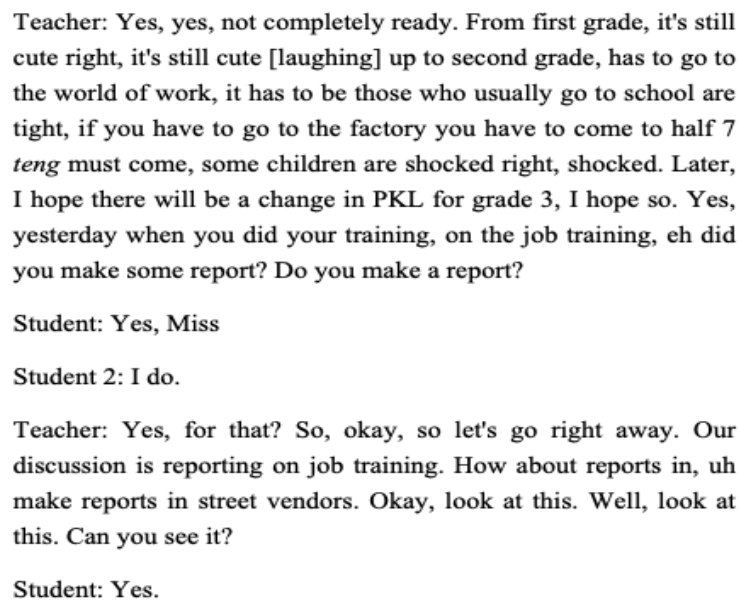

Figure 5 taken from video document observation's transcription 4.

After presenting the learning aim, she began to explain the topic discussion by showing the pictures, elaborating language features such as the past tense. After that, she gave the example of report writing, analysed the report writing features, and assigned the 
exercises. At the end of the class, she gave the assignment through google classroom.

At the fourth Zoom recording, the researchers found the teacher kept engaged with the students, conveying the learning aim, writing an application letter. She guided the students to seek job application information from the news media.

All observation findings it was depicting that the teacher was involved with friendly conversations. She often gave appraisals to the students who actively responded to her. Consequently, the students were very active in learning English in every class. As confirmed by Willms et al. (2009), open, caring, supportive relationships are essential for social and psychological learning engagement. It is also in line with Claxton (2007) that learning relates to real-life scenarios builds meaning. Suherdi (2018) also revealed that the learning interaction framework is essential for synergistic multilayered students. Also, Brown (2000) believed that media technology reform language, mainly spoken language.

Thus, EFL students' engagement with various dimensions: behaviours, emotions, involvement, and cognition may be strengthened by English online learning platforms such as Zoom meetings, Google classrooms, and forum discussions through WAG. It is as believed by Fredricks and McColsky (2012), Zake et al. (2010), as cited in Purnawarman, Susilawati, and Sundayana (2016), Zhang and McNamara (2018) assert that student and teacher engagement conceptualizations describe three main fields of interaction: behaviours, motivations, relationships. And also, Dixson (2015) contended the OSE on behaviours, thoughts, and feelings. The students' engagement aspects in English online learning contribute three vital dimensions: to facilitate an investigation into online class platforms, to provide a review to teachers about the engagement intensity of their students, and to offer evidence of teaching competence. This teaching strategy may succeed by increasing motivation to the students to improve learning engagement types, as Saeed and Zyngier (2012), Mahboob and Elyas (2014), and BleyVroman in Anis \& Anwar (2020) believed. Similar to Bundick et al. (2014), motivated and engaged students can learn better, and they show the best possible academic study outcomes, as cited by Anis and Anwar (2020). It may also influence our nation and its sustainability aspects. However, these students' engagement should deploy appropriate pedagogies so that teachers can make classrooms more engaging places for students to learn as (Saeed \& Zyngier, 2012) asserted. And the educators should think that EFL teachers' can seek appropriate online EFL learning approaches that involve testing students' engagement, providing grades, and synchronizing scores on an agreed platform, as Atmojo and Nugroho (2020) reported in their study. Then, EFL students can achieve the best possible academic study outcomes.

\section{CONCLUSION}

English online learning platforms such as Zoom meetings, Google classrooms, and forum discussions through WAG can help students' engagement with English online learning. This teaching strategy may succeed by increasing motivation to the students to improve learning engagement types. The educators should consider that EFL teachers can seek appropriate online EFL learning approaches that involve testing students' engagement, providing grades, and synchronizing scores on an agreed platform. Thus, students can obtain the best academic study outcomes.

\section{REFERENCES}

Anis, M., \& Anwar, C. (2020). Self-organized learning environment teaching strategy for ELT in Merdeka Belajar concept for high school students in Indonesia. JEES (Journal of English Educators Society), 5(2), 199-204.

Aspers, P., \& Corte, U. (2019). What is qualitative in qualitative research. Qualitative sociology, 42(2), 139-160.

Atmojo, A. E. P., \& Nugroho, A. (2020). EFL classes must go online! Teaching activities and challenges during COVID-19 pandemic in Indonesia. Register Journal, 13(1), 49-76.

Austin, Z., \& Sutton, J. (2014). Qualitative research: Getting started. The Canadian journal of hospital pharmacy, 67(6), 436.

Brown, J. S. (2000). Growing up: Digital: How the web changes work, education, and the ways people learn. Change: The Magazine of Higher Learning, 32(2), 11-20.

Bundick, M. J., Quaglia, R. J., Corso, M. J., \& Haywood, D. E. (2014). Promoting student engagement in the classroom. Teachers College Record, 116(4).

Claxton, G. (2007). Expanding young people's capacity to learn. British journal of educational studies, 55(2), 115-134.

Dixson, M. D. (2015). Measuring student engagement in the online course: The Online Student Engagement scale (OSE). Online Learning, 19(4), 1-15.

Dunleavy, J., \& Milton, P. (2009). What did you do in school today? Exploring the concept of fostering learning. Learning Environment Research, 3, 135158. 
Fredricks, J. A., \& McColskey, W. (2012). The measurement of student engagement: A comparative analysis of various methods and student self-report instruments. In S. L Christenson, A. L. Reschly \& C. Wylie (Eds.), Handbook of research on student engagement (pp. 763-782). Springer.

JASP Team (2020). JASP (Version 0.13) [Computer software].

Jansen, H. (2010). The logic of qualitative survey research and its position in the field of social research methods. Qualitative Social Research, 11(2).

Mahboob, A., \& Elyas, T. (2014). English in the kingdom of Saudi Arabia. World Englishes, 33(1), 128-142.

Paltridge, B., \& Starfield, S. (2013). ESP and language skills. In B. Paltridge, \& S. Starfield (Eds.), The handbook of English for specific purposes (pp. 3134). Chichester, UK: John Wiley \& Sons, Inc.

Parsons, J., \& Taylor, L. (2011). Improving student engagement. Current issues in education, 14(1).

Purnawarman, P., Susilawati, S., \& Sundayana, W. (2016). The use of Edmodo in teaching writing in a blended learning setting. Indonesian Journal of Applied Linguistics, 5(2), 242-252.

Saeed, S., \& Zyngier, D. (2012). How motivation influences student engagement: A qualitative case study. Journal of Education and Learning, 1(2), 252-267.

Setyarini, S., Muslim, A. B., Rukmini, D., Yuliasri, I., \& Mujianto, Y. (2018). Thinking critically while storytelling: Improving children's HOTS and English oral competence. Indonesian Journal of Applied Linguistics, 8(1), 189-197.

Subkhan, E. (2020). What is new on curriculum policy and how it affects curriculum studies? Indonesian Journal of Curriculum and Educational Technology Studies, 8(1), 56-61.

Suherdi, D. (2018). SMSLEFA: An alternative synergistic multilayered analysis of students' learning engagement in EFL context. Indonesian Journal of Applied Linguistics, 8(1), 11-20.

Willms, J. D., Friesen, S., \& Milton, P. (2009). What did you do in school today? Transforming classrooms through social, academic, and intellectual engagement. First National Report.

Zhang, Z., \& McNamara, O. (2018). Undergraduate student engagement: Theory and practice in China and the UK. Springer. 